\title{
Pancreatic Proteolytic Enzymes
}

National Cancer Institute

\section{Source}

National Cancer Institute. Pancreatic Proteolytic Enzymes. NCI Thesaurus. Code C38728.

Enzymes produced and secreted by the pancreas which aid in the proteolysis of proteins in the digestive tract. Pancreatic proteolytic enzymes include trypsin, chymotrypsin and carboxypeptidase; these enzymes are secreted as zymogens, inactive precursors of the enzymes, and are activated in the lumen of the digestive canal. Another proteolytic enzyme, enteropeptidase, is associated with the brush border of enterocytes; this enzyme catalyses the conversion of trypsinogen into trypsin which, in turn, can activate a number of other pancreatic zymogens. ( $\mathrm{NCl} 04)$ 